\title{
Digestibility of pelleted rations containing diverse potato flour and urea
}

\author{
Degradabilidade ruminal e digestibilidade in vitro de rações peletizadas contendo \\ farinha de batata diversa e ureia
}

\author{
Isabel Martinele ${ }^{\mathrm{I}}$ Paulo César de Aguiar Paiva ${ }^{\mathrm{II}}$ Fernando César Ferraz Lopes ${ }^{\mathrm{II}}$ \\ Juliana de Cássia Pereira ${ }^{I I}$ Ludhiana Rosa Ferreira ${ }^{\text {II }}$
}

ABSTRACT

The aim of this study was to evaluate ruminal in situ degradability and in vitro digestibility of dry matter (DM) in concentrate supplements containing diverse potato flour pelletized with urea $(0 \%, 4 \%, 8 \%$, and 12\% DM). Samples of feeds were incubated for 0, 2, 4, 8, 12, 24, 36, and 48h in the rumen of four fistulated sheep. Level of urea added had no significant effect $(P>0.05)$ on the soluble fraction (a) or potentially degradable fraction (b) of the pellets and ranged from $2.1 \%$ to $12.2 \%$ and $72.9 \%$ to $87.5 \%$, respectively. Quadratic effects $(P=0.03)$ of the rate of degradation of fraction " $b$ " ranged from $4.75 \% h^{-1}$ to $7.39 \% \mathrm{~h}^{-1}$; the estimated maximum value at $7.4 \% h^{-1}$ was obtained when $5.9 \%$ urea was added to the pellet. Quadratic effects $(P \leq 0.02)$ of the level of urea added to the pellets on the effective degradability (ED) of DM were evaluated after considering rumen passage rates of $2.5 \% h^{-1}$ and $8 \% h^{-1}$; the maximum values of ED calculated under these rumen passage rates were estimated at $6.3 \%$ to $7.3 \%$ urea in the pellets. The in vitro digestibility of DM of the pellets showed a quadratic effect $(P=0.02)$ at different levels of urea, with a maximum value of $96.9 \%$ achieved when $7.9 \%$ urea was added to the pellets. Our results suggest that the addition of 6-8\% urea to pelleted feed promotes an increase in the in vitro digestibility and ED of DM.

Key words: alternative feeds, pelletization, ruminants, Solanum tuberosum.

\section{RESUMO}

Objetivou-se avaliar a degradação ruminal in situ da matéria seca (MS) e a digestibilidade in vitro de suplementos concentrados a base de farinha de batata diversa peletizada com ureia $(0,4,8$ e $12 \%$ da MS). Amostras de cada tratamento foram incubadas por 0, 2, 4, 8, 12, 24, 36 e 48 horas no rúmen de quatro ovinos fistulados. Não houve efeito $(P>0,05)$ do nivel de inclusão de ureia sobre as frações solúvel (" $a$ ") e potencialmente degradável
(" $b$ ") dos péletes, que variaram, respectivamente, de 2,1 a 12,1\%, e de 72,9 a 87,5\%. Foi observado efeito quadrático $(P=0,03)$ para a taxa de degradação da fração " $b$ ", que variou de 4,75 a 7,39\% $h^{-1}$, sendo o valor máximo estimado em $7,4 \% h^{-1}$, obtido quando $5,9 \%$ de ureia foram incluidos no pélete. Foram observados efeitos quadráticos $(P \leq 0,02)$ do nivel de inclusão de ureia nos péletes sobre a degradabilidade efetiva (DE) da MS, considerando taxas de passagem no rúmen de 2, 5 e $8 \% h^{-1}$ e os valores máximos de DE calculadas sob estas taxas de passagem no rúmen foram estimados com 6,3 a 7,3\% de ureia nos péletes. A digestibilidade in vitro da MS dos péletes foi influenciada de forma quadrática $(P=0,02)$ pelo nível de inclusão de ureia, com valor máximo de 96,9\%, estimado quando 7,9\% de ureia foram incluídos no pélete. A inclusão de 6 a $8 \%$ de ureia nos péletes promove incremento na digestibilidade in vitro e na degradabilidade efetiva da matéria seca.

Palavras-chave: alimentos alternativos, peletização, ruminantes, Solanum tuberosum.

\section{INTRODUCTION}

The state of Minas Gerais is the leading producer of potatoes (Solanum tuberosum L.) in Brazil, both in terms of crop growth estimates and production areas (Instituto Brasileiro de Pesquisa Agropecuária - IBGE, 2013). However, a large quantity of potatoes do not meet the market standards because of damage caused during harvesting and processing, and these losses increase during periods of high availability of potatoes in the market.

These discarded potatoes are a type of crop residue called "diverse potatoes", which

IDepartamento de Zoologia, Universidade Federal de Juiz de Fora (UFJF), 36036-900, Juiz de Fora, MG, Brasil. E-mail: isabelmartinele@yahoo.com.br. Corresponding author.

IIDepartamento de Zootecnia, Universidade Federal de Lavras (UFLA), Lavras, MG, Brasil.

IIIEmbrapa Gado de Leite, Juiz de Fora, MG, Brasil. Received 08.20.14 Approved 04.07.15 Returned by the author 07.14.15 CR-2014-1234.R3 
consist of tubers that failed to reach commercial standards (REZENDE et al., 2007), and they can be used as ruminant feed. However, potatoes are rapidly perishable and their production period is of few months, which makes their use as animal feed discontinuous. Thus, methods to promote the conservation of potatoes and extend their shelf life are necessary. Silage of diverse potato bran (REZENDE et al., 2007) or of other waste generated during industrial processing (SUGIMOTO et al., 2007, 2008) is the most widely adopted conservation method.

Pelletization can be used as an alternative method to recover potato residues, and it can promote the elimination of contaminating microorganisms, increase shelf life, make transportation and storage easier, and allow the addition of other ingredients to the residue.

Diverse potato flour mixed with urea and pelletized, similar to Starea (extruded starch + urea product; SALVADOR et al., 2004), can promote a gradual release of ammonia in the rumen, possibly reducing the risk of urea poisoning and improving the synthesis of microbial proteins.

Thus, the aim of this study was to evaluate in situ rumen degradability and in vitro digestibility of dry matter (DM) of concentrated supplements formulated using pelleted diverse potato flour with varying levels of urea.

\section{MATERIAL AND METHODS}

Diverse potatoes were ground in a stationary forage chopper to obtain pieces of an average size of $2 \mathrm{~cm}$. Subsequently, the potato pieces were dried in the sun until they had a moisture level of $15 \%$, and they were then ground. The flour obtained was mixed with other ingredients (Table 1) to facilitate pelletization and to improve nutritional adequacy. Urea was added to the pellets at increasing levels $(0 \%, 4 \%, 8 \%$, and $12 \% \mathrm{DM}$ ), and four treatments were established (Table 1). Ingredients were mixed and pelletized in a 3/8 matrix HP7.5 pelletizer.

Rumen degradability test was conducted using a $4 \times 4$ Latin square (LS) design. Four male sheep (average body weight, $46.0 \pm 5.3 \mathrm{~kg}$ ) of an undefined breed were used. Each sheep was fitted with a rumen cannula. The animals' diet consisted of coarsely ground Tifton 85 grass hay (Cynodon spp.) comprising 90.7\% DM, 9.5\% crude protein, and $76.6 \%$ neutral detergent fiber (NDF), and it was provided daily at $7 \mathrm{AM}$ and 5 PM. The amount provided was approximately $3 \%$ of their body weight and was adjusted to account for leftovers of around $20 \%$. Water and mineral supplements were provided ad libitum.

The incubation bags were made of nonwoven fabric $\left(100 \mathrm{~g} / \mathrm{m}^{2}\right)$ and measured $9.0 \times 14.0 \mathrm{~cm}$ (MONTEILS et al., 2002); dried in a forced ventilation oven at $65^{\circ} \mathrm{C}$ for $48 \mathrm{~h}$; weighed; and filled with $4 \mathrm{~g}$ of the evaluated feed (ØRSKOV, 1992), which had been previously ground into 2-mm pieces (NOCEK, 1988). Feeds were incubated as recommended by NOCEK (1988) for $0,2,4,8$, $12,24,36$, and $48 \mathrm{~h}$, according to a method used in previous studies (ØRSKOV, 1992; TEIXEIRA et al., 1999; MONTEILS et al., 2002).

A total of 384 bags (four sheep $\times$ four treatments $\times$ eight times $\times$ three replicates) were

Table 1 - Composition of pelleted rations containing diverse potato flour and urea.

\begin{tabular}{|c|c|c|c|c|}
\hline \multirow{2}{*}{ Composition } & \multicolumn{4}{|c|}{--Urea level in the pellet (\%)--- } \\
\hline & 0 & 4 & 8 & 12 \\
\hline \multicolumn{5}{|l|}{ Ingredients ( $\%$ dry matter) } \\
\hline Diverse potato flour & 60 & 60 & 60 & 60 \\
\hline Corn milled & 20 & 20 & 20 & 20 \\
\hline Wheat Bran & 17 & 13 & 09 & 05 \\
\hline Molasses & 03 & 03 & 03 & 03 \\
\hline Urea + Ammonium sulfate $(9: 1)$ & 0 & 4 & 8 & 12 \\
\hline Dry matter & 87.9 & 89.8 & 88.7 & 85.1 \\
\hline Mineral matter & 8.9 & 8.1 & 8.1 & 8.6 \\
\hline Organic matter & 79.0 & 81.7 & 80.6 & 76.4 \\
\hline Starch & 52.7 & 55.7 & 52.1 & 51.4 \\
\hline Crude protein & 8.9 & 19.8 & 28.8 & 36.7 \\
\hline Neutral detergent fiber & 12.3 & 11.2 & 10.7 & 9.5 \\
\hline Ether extract & 0.8 & 1.3 & 0.6 & 0.9 \\
\hline
\end{tabular}


incubated and distributed so that each animal received all three repetitions of each of the four treatments and in each phase of LS. Because of the small volume of sheep rumen, each animal received the bags for varying periods of decreasing duration, i.e., 48-, 36-, and 24-h periods, and were simultaneously withdrawn for further incubation for other periods. After the bags were removed, they were placed in a container with ice in order to halt fermentation and were subsequently frozen so all bags were simultaneously washed at the end of each incubation. The bags at time zero were placed in the container with ice and immediately removed, thereby receiving the same treatment as the other bags.

For washing, bags were placed in a container with water until the residue of the rumen contents was completely removed. After drying in an oven at $65^{\circ} \mathrm{C}$ for $72 \mathrm{~h}$, bags were weighed, and the remaining residues were analyzed for DM content.

Ruminal degradation parameters of DM were estimated using the Marquardt algorithm iterative process, according to the procedure for nonlinear models (PROC NLIN; SAS, 2004). Data from partial degradation of DM for each treatment were adjusted per sheep, according to the equation proposed by MEHREZ \& ØRSKOV (1977), and subsequently subjected to linear and quadratic regression analyses $(\alpha=0.05)$ using PROC REG (SAS, 2004). Effective degradability (ED) values of DM were calculated according to the method proposed by ØRSKOV \& MCDONALD (1979), adopting passage rates of $2 \%$ $\mathrm{h}^{-1}, 5 \% \mathrm{~h}^{-1}$, and $8 \% \mathrm{~h}^{-1}$ in the rumen (ARC, 1980).
To evaluate in vitro digestible dry matter (IVDDM), rumen fluid was obtained from a fistulated male sheep of an undefined breed. The animal, which was adapted to consume pelleted diverse potato flour with urea, was fed with Tifton 85 grass hay and water, mineral salts, and supplementary feed were provided ad libitum. Contents of the rumen were collected before the morning feed and were immediately filtered. An artificial saliva solution was added to the rumen fluid at a 4:1 ratio, and it was then incubated with $5 \mathrm{~g}$ each of the tested feeds, according to the two-stage technique described by TILLEY \& TERRY (1963). After incubation, the remaining content of each tube was oven-dried at $105^{\circ} \mathrm{C}$ for $12 \mathrm{~h}$, weight of the residue was determined, and the residue was then analyzed for DM content.

The effect of urea levels on IVDDM was evaluated using a completely randomized design with six replicates through analyses of linear and quadratic regression $(\alpha=0.05)$ with PROC REG (SAS, 2004). LSMEANS of the GLM procedure was adopted to generate mean and standard error values.

\section{RESULTS AND DISCUSSION}

The amount of urea in the pellets had no effect $(P>0.05)$ on the soluble (a) and potentially degradable (b) fractions (Table 2). These were considerably different from the fractions obtained for Starea, containing corn or cassava, with values ranging from $30.5 \%$ to $36.5 \%$ for fraction "a" (TEIXEIRA et al., 1999), as well as the silage of

Table 2 - Ruminal in situ degradation of dry matter of pelleted rations containing diverse potato flour and urea.

\begin{tabular}{|c|c|c|c|c|c|c|}
\hline \multirow{2}{*}{ Variable $^{1}$} & \multicolumn{4}{|c|}{-Urea level in the pellet (\%)--------- } & \multirow{2}{*}{$\mathrm{SEM}^{2}$} & \multirow{2}{*}{ Regression equation and $\mathrm{P}$ value } \\
\hline & 0 & 4 & 8 & 12 & & \\
\hline a (\%) & 7.1 & 2.1 & 12.1 & 4.3 & 2.2 & $\mathrm{y}=6.43(P=0.91)$ \\
\hline $\mathrm{b}(\%)$ & 78.2 & 85.2 & 72.9 & 87.5 & 2.8 & $\mathrm{y}=80.96(P=0.42)$ \\
\hline $\mathrm{c}(\% / \mathrm{h})$ & 5.1 & 6.8 & 7.3 & 4.7 & 0.9 & $\begin{array}{l}\mathrm{y}=5.05513+0.80159 X-0.06824 X^{2} \\
\mathrm{r}^{2}=0.31 ; P=0.03\end{array}$ \\
\hline $\mathrm{PD}(\%)$ & 85.4 & 87.3 & 85.0 & 91.9 & 2.1 & $\mathrm{y}=87.40(\mathrm{P}=0.18)$ \\
\hline ED2 (\%) & 61.9 & 67.0 & 68.9 & 65.7 & 1.2 & $\begin{array}{l}y=61.85325+1.89269 X-0.13008 X^{2} \\
r^{2}=0.44 ; P=0.02\end{array}$ \\
\hline ED5 (\%) & 45.6 & 50.3 & 55.0 & 46.8 & 1.1 & $\begin{array}{l}y=45.01163+2.62416 X-0.20176 X^{2} \\
r^{2}=0.45 ; P=0.01\end{array}$ \\
\hline ED8 (\%) & 37.0 & 40.5 & 46.6 & 36.8 & 1.1 & $\begin{array}{l}\mathrm{y}=36.07738+2.65872 \mathrm{X}-0.21012 \mathrm{X}^{2} \\
\mathrm{r}^{2}=0.40 ; \mathrm{P}=0.01\end{array}$ \\
\hline
\end{tabular}

${ }^{1}$ where: $\mathrm{a}=$ soluble fraction; $\mathrm{b}=$ potentially degradable insoluble fraction; $\mathrm{c}=$ rate of degradation of fraction $\mathrm{b}$; PD = potential degradability $(\mathrm{a}+\mathrm{b}) ; \mathrm{ED} 2, \mathrm{ED} 5, \mathrm{ED} 8=$ effective degradability considering passage rate in the rumen of $2 ; 5$ and $8 \% \mathrm{~h}^{-1}$.

${ }^{2}$ Standard error of the mean. 
potato with or without urea treatment $(30.3 \%$ and $38 \%$, respectively) (SUGIMOTO et al., 2007).

Rumen degradability of starch in different feeds varied from $18.4 \%$ to $87.3 \%$ for fraction "a". Soluble fraction of starch obtained by washing the bags at time zero could be overestimated because of the loss of particles from inside the bag, thereby influencing the rumen degradability values of feeds and jeopardizing the estimate of parameters " $b$ " and "c" (ZEOULA et al., 1999). Thus, factors such grain size and the source of grain and feed may influence starch degradability (GIUBERTI et al., 2013).

A quadratic effect $(P=0.03)$ was observed for degradation rate "c," which ranged from $4.75 \%$ $\mathrm{h}^{-1}$ to $7.39 \% \mathrm{~h}^{-1}$ (Table 2); the maximum value estimated was $7.41 \% \mathrm{~h}^{-1}$, and it was obtained when $5.9 \%$ urea was included in the pellet. The values observed (Table 2) were close to $6.6 \% \mathrm{~h}^{-1}$ obtained for Starea $45 \mathrm{~S}$, with ground corn being the source of starch (TEIXEIRA et al., 1999). The values $6.3 \% \mathrm{~h}^{-1}$ and $6.5 \% \mathrm{~h}^{-1}$ were obtained for the silage of potato pulp with or without treatment with $0.5 \%$ urea, respectively (SUGIMOTO et al., 2007); and $7.4 \% \mathrm{~h}^{-1}$ and $6.4 \% \mathrm{~h}^{-1}$ for the silage of potato pulp with soybean meal or corn gluten, respectively (SUGIMOTO et al., 2008).

Quadratic effects $(P \leq 0.02)$ of urea content in pellets on the ED of DM have been observed, considering passage rates of $2 \% \mathrm{~h}^{-1}, 5 \% \mathrm{~h}^{-1}$, and $8 \%$ $\mathrm{h}^{-1}$ in the rumen (Table 2). Maximum ED values calculated under these passage rates in the rumen were estimated when $6.3-7.3 \%$ urea was included in the pellets. ED of DM estimated for $8 \%$ urea in the potato flour pellet $(55 \%)$, considering a passage rate of $5 \% \mathrm{~h}^{-1}$ in the rumen, was similar to that recorded for Starea $45 \mathrm{~S}$ with corn as a source of starch in whole, broken, or in ground form $(56.8 \%, 54 \%$, and $57.4 \%$, respectively). This indicates that pelletization permits synchronization between starch and urea release, which promotes microbial growth in the rumen (TEIXEIRA et al., 1999).

IVDDM of concentrated supplements was influenced in a quadratic manner $(P=0.02)$ by the urea content in the pellet (Table 3), and the maximum value estimated was $96.9 \%$ when $7.9 \%$ urea was included in the pellet. This value is higher than the IVDDM of sun-dried potato peel residue (85.4\%), which may be due to the high NDF concentration in the potato peel residue (41\%; TAWILA et al., 2008) in comparison with treatments with diverse potato flour with an average NDF content of $11 \%$.

The high values observed for IVDDM may result in increased DM intake and passage rate through the rumen (MALLMANN et al., 2006). This is relevant since the passage rate interferes with the reduction of the average age of microbiota because of removal of mature organisms. Thus, the energy required to maintain microbiota is reduced, thereby increasing the efficiency of energy use in the system for microbial growth (SALVADOR et al., 2004).

To increase the level of ammonia derived from degradable proteins or non-protein nitrogen sources in the rumen, IVDDM can be increased without necessarily increasing microbial activity, primarily in diets containing highly soluble urea (CALDAS NETO et al., 2007) because rumen microbiota have nitrogen requirements that are beyond the availability of ammonia (FIRKINS, 2010).

Levels of urea added to the pellet that was estimated to reach the maximum value for fraction "c" was $5.9 \%$. For ED, it ranged from $6.3 \%$ to $7.3 \%$ for a maximum IVDDM of $7.9 \%$. When the nutritional quality of the pellets was evaluated on the basis of these parameters, levels of urea in the pellets ranged from $5.9 \%$ to $7.9 \%$ or, in practice, $6-8 \%$. Synchronization of carbohydrate and urea digestion rates in the rumen theoretically increases efficiency of microbial protein synthesis, promoting an optimal rumen environment to maintain animal health and consequently increase DM intake and productivity (TEIXEIRA, 1999). Addition of various levels of urea to the pellets resulted in a more available nitrogen for microbial activity, thereby culminating in higher ruminal degradability and IVDDM. However, branched-chain fatty acids and peptides may become a limiting factor for

Table 3 - In vitro digestibility of dry matter (\%) of pelleted rations containing diverse potato flour and urea.

\begin{tabular}{|c|c|c|c|c|c|}
\hline & -- & --Urea & ellet $(\%$ & 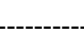 & \multirow{2}{*}{ Regression equation and $\mathrm{P}$ value } \\
\hline & 0 & 4 & 8 & 12 & \\
\hline Mean & 92.06 & 96.29 & 96.42 & 95.87 & $\mathrm{y}=92.23467+1.18533 X-0.07469 X^{2}$ \\
\hline SEM $^{1}$ & 0.88 & 0.88 & 0.88 & 0.88 & $\mathrm{r}^{2}=0.36 ; \mathrm{P}=0.02$ \\
\hline
\end{tabular}

${ }^{1}$ Standard error of the mean. 
microbial activity at inclusion values above the $6-8 \%$ range, which partially explains the quadratic behavior observed for the degradation rate (c), ED, and IVDDM. Therefore, it is advisable to add $6-8 \%$ urea to pelleted feed made from diverse potato flour.

\section{CONCLUSION}

Our results suggest that we need to pelletize diverse potato flour and add $6-8 \%$ urea to obtain a large increase in the in vitro digestibility and ED of DM.

\section{BIOETHICS AND BIOSSECURITY COMMITTEE APPROVAL}

The procedures used during the animal experiments comply with the resolutions of Conselho Nacional de Controle de Experimentação Animal (CONCEA).

\section{ACKNOWLEDGEMENTS}

This work was supported by Conselho Nacional de Desenvolvimento Científico e Tecnológico (CNPq) (Process: 472606/2008-5). We like to thank Associação dos Bataticultores de Minas Gerais (ABASMIG) the supply of potatoes and Coordenação de Aperfeiçoamento de Pessoal de Nível Superior (CAPES) for the Scholarship granted to I. Martinele.

\section{REFERENCES}

ARC (AGRICULTURAL RESEARCH COUNCIL). The nutrient requirements of ruminant livestock. London: The Gresham, 1980. 351p

CALDAS NETO, S.F. et al. Proteína degradável no rúmen associada a fontes de amido de alta ou baixa degradabilidade: digestibilidade in vitro e desempenho de novilhos em crescimento. Revista Brasileira de Zootecnia, v.36, n.2, p.452-460, 2007. Available from: <http:/www.revista.sbz.org.br/artigo/visualizar. php? artigo $=5216>$. Accessed: Feb. 12, 2014. doi: 10.1590/S151635982008000600021.

FIRKINS, J.F. Reconsidering rumen microbial consortia to enhance feed efficiency and reduce environmental impact of ruminant livestock production systems. Revista Brasileira de Zootecnia, v.39, p.445-457, 2010 (supl. especial). Available from: <http://www.scielo.br/scielo.php?pid=S151635982010001300049\&script $=$ sci_arttext $>$. Accessed: Mar. 23, 2015. doi: 10.1590/S1516-35982010001300049.

GIUBERTI, G. Factors affecting starch utilization in large animal food production system: a review. Starch/Stärke, v.65, p.119, 2013. Available from: <http://istituti.unicatt.it/nutrizione Pubb 2013 Starch.PDF>. Accessed: Mar. 23, 2015. doi: 10.1002/ star. 201300177 .

IBGE (INSTITUTO BRASILEIRO DE GEOGRAFIA E ESTATÍSTICA). Indicadores IBGE Estatística da Produção Agrícola, 2013. Available from: <http://www.ibge.gov.br/home/ estatistica/indicadores/agropecuaria/lspa/estProdAgr_201309.p >. Accessed: Mar. 10, 2014
MALLMANN, G.M. et al. Consumo e digestibilidade de feno de baixa qualidade suplementado com nitrogênio não protéico em bovinos. Pesquisa Agropecuária Brasileira, v.41, n.2, p.331-337, 2006. Available from: <http://www.scielo. br/scielo.php?pid=S0100-204X2006000200019\&script $=$ sci arttext>. Accessed: Mar. 23, 2015. doi: 10.1590/S0100204X2006000200019.

MEHREZ, A.Z.; ØRSKOV, E.R. A study of the artificial fibre bag technique for determining the digestibility of feeds in the rumen. Journal Agricultural Science, v.88, n.3, p.645-650, 1977. Available from: $<$ http://journals.cambridge.org/action/displayAbst ract fromPage $=$ online \&aid $=4595608>$. Accessed: Feb. 12, 2014. doi: $10.1017 / \mathrm{S} 0021859600037321$.

MONTEILS, V. et al. Kinetics of ruminal degradation of wheat and potato starches in total mixed rations. Journal of Animal Science, v.80, n.1, p.235-241, 2002. Available from: <http:// www.journalofanimalscience.org/content/80/1/235.long $>$. Accessed: Feb. 12, 2014.

NOCEK, J.E. In situ and others methods to estimate ruminal protein and energy digestibility: a review. Journal of Dairy Science, v.71, n.8, p.2051-2059, 1988. Available from: $<$ http://www.sciencedirect. com/science/article/pii/S0022030288797817>. Accessed: Feb. 12, 2014. doi: 10.3168/jds.S0022-0302(88)79781-7.

ØRSKOV, E.R. Protein nutrition in ruminants. 2.ed. London: Academic, 1992. 175p.

ØRSKOV , E.R.; McDONALD, T. The estimation of protein degradability in the rumen from incubation measurements weighted according to rate passage. Journal of Agricultural Science, v.92, n.2, p.499-503, 1979. Available from: < http://journals.cambridge. org/action $/$ displayAbstract? fromPage $=$ online $\&$ aid $=4777356>$. Accessed: Feb. 12, 2014. doi:10.1017/S0021859600063048.

REZENDE, V.M. et al. Degradabilidade ruminal das silagens de capim-Napier produzidas com diferentes níveis de farinha de "batata diversa". Ciência e Agrotecnologia, v.31, n.02, p.485491, 2007. Available from: <http://www.scielo.br/pdf/cagro/ v31n2/a32v31n2.pdf>. Accessed: Feb. 12, 2014. doi: 10.1590/ S1413-70542007000200032.

SALVADOR, F.M. et al. Utilização de amiréias (produto da extrusão amido + uréia) com diferentes proporções de uréia: 1. Consumo e digestibilidade aparente da matéria seca, fibra em detergente neutro e fibra em detergente ácido. Ciência e Agrotecnologia, v.28, n.1, p.199-205, 2004. Available from: <http://www.scielo.br/pdf/cagro/ v28n1/a27.pdf>. Accessed: Feb. 12, 2014. doi: 10.1590/S141370542004000100027

SAS INSTITUTE. SAS/STAT user's guide. Cary: SAS Institute, 2004. 675p.

SUGIMOTO, M. et al. The effects of protein sources supplemented with urea-treated potato pulp (PP) silage and feeding levels of the PP silage-based concentrate on feed intake, digestibility and ruminal fermentation in beef steers. Animal Science Journal, v.79, n.4, p.443-452, 2008. Available from: <http://onlinelibrary.wiley.com/ doi/10.1111/j.1740-0929.2008.00548.x/pdf>. Accessed: Feb. 12, 2014. doi: 10.1111/j.1740-0929.2008.00548.x.

SUGIMOTO, M. et al. Effects of urea treatment of potato pulp and inclusion levels of potato pulp silage in supplements on digestibility and ruminal fermentation in beef steers. 
Animal Science Journal, v.78, n.6, p.587-595, 2007. Available from: <http://onlinelibrary.wiley.com/doi/10.1111/ j.1740-0929.2007.00479.x/pdf>. Accessed: Feb. 12, 2014. doi: 10.1111/j.1740-0929.2007.00479.x.

TAWILA, M.A. et al. Partial replacing of concentrate feed mixture by potato processing waste in sheep rations. American-Eurasian Journal of Agriculture \& Enviromental, v.4, n.2, p.156-164, 2008. Available from: $<\mathrm{http} / / /$ www.idosi.org/aejaes/jaes4(2)/5.pdf $>$. Accessed: Feb. 12, 2014.

TEIXEIRA, J.C. et al. Cinética da digestão ruminal da amiréia 45-s em vacas da raça holandesa. Ciência e Agrotecnologia, v.23, n.3, p.719-723, 1999. Available from: <http://www.editora.ufla.br/index. $\mathrm{php} /$ component/phocadownload/category/33-volume-23-numero3?download=458:vol23numero3>. Accessed: Feb. 12, 2014.

TILLEY, J.M.A.; TERRY, R.A. A two stage technique for the in vitro digestion of forage crops. Journal of the British Grassland Society, v.18, p.104-111, 1963. Available from: <http://onlinelibrary.wiley. com/doi/10.1111/j.1365-2494.1963.tb00335.x/pdf > . Accessed: Feb. 2014. doi: 10.1111/j.1365-2494.1963.tb00335.x.

ZEOULA, L.M. et al. Solubilidade e degradabilidade ruminal do amido de diferentes alimentos. Revista Brasileira de Zootecnia, v.28, n.5, p.905-912, 1999. Available from: <http://www.sbz. org.br/revista/artigos/2332.pdf $>$. Accessed: Jun. 23, 2013. doi: 10.1590/S1516-35982003000200030. 